\title{
Turbines and turbulence
}

\section{Some legitimate questions have been raised over the green credentials of wind turbines. Politics must not block research where it is needed.}

W ill wind turbines wreck the environment? Last month, the South China Morning Post published a news story that contained a thinly veiled attack on China's wind industry. The article cited herdsmen in a village in Inner Mongolia who say rain stopped falling after the establishment of a nearby wind farm, and meteorologists who backed up the observation with a few years' data that show low precipitation. The article also quoted an engineer in the government's renewable-energy department who hastily dismissed concern over the effect of wind farms, refused to acknowledge the need for research, and asserted the overarching necessity for China to develop wind energy. The article concludes that "wind power is not completely green". There have been similar attacks on wind energy in Texas and elsewhere.

It is good to see that the newspaper, Hong Kong's most prominent English-language daily, retains a critical stance towards the Chinese government under the 'one country, two systems' policy, and is willing to put Chinese officials on the spot. But in this case, the dismissive official quoted probably has a point. There is no solid scientific evidence that wind turbines can trigger major changes in rainfall. And given Nature's conversations with atmospheric modellers outside China, people are not likely to find any. One expert said the idea that a wind farm could have such a dramatic and demonstrable effect was "silly".

Wind farms, however, may affect regional or global environmental systems - although to suggest this can draw rapid scorn from windpower proponents. In 2004, the environmental engineer and atmospheric modeller Somnath Baidya Roy, then at Princeton University in New Jersey, published work showing turbulence created by turbines would, among other effects, lead to vertical mixing of energy and heat in atmospheric layers that would affect local temperatures, and possibly change evaporation patterns (S. B. Roy et al. J. Geophys. Res. 109, D19101; 2004). Some took his study as an attack on the wind industry, and he was besieged with nasty e-mails. They questioned his sanity, threatened to get him fired from his post at Princeton, and accused him of being a pawn of the coal or oil industries. (He has never had nor sought any industrial ties.) The president of one US-based wind-farm firm told Roy to consider "how much heat is your head turning out, while you consider such thoughts?" and to ponder many other factors "while checking your navel for lint". (We know this because Roy considered the comments humorous enough to post on his webpage.)

At around the same time, other scientists used models to suggest that wind turbines could have effects on climate change and suggested that estimates of these effects should be balanced against their green benefits. Although these researchers are seen by some in the industry as overly critical, they concluded with no stronger recommendation than a call for more research.

In October, Roy, now at the University of Illinois at UrbanaChampaign, published data to back up his theoretical work (S. B. Roy and J. J. Traiteur Proc. Natl Acad. Sci. USA 107, 17899-17904; 2010).

A 25-year data set showed a significant effect of wind farms on nearsurface temperatures. Roy suggested in the paper that those constructing wind farms should consider low-turbulence turbines or use the results to help find the most suitable sites. It hardly constituted an attack on wind energy. In fact, he says, the main impact - a raising of

"Datashowed a significant effect of wind farms on

near-surface temperatures.' field campaign that can monitor energy fluxes, evaporation, humidity and temperature on a variety of farms as they scale up.

China, developing huge wind farms and planning more, should take a prominent role in such studies. As its facilities expand, it can make solid scientific assessments, which could contribute to a more rational and beneficial use of wind. Although the Chinese official may have been right to dismiss the suggested effect on rainfall, his government should not ignore the need for wider research on the impact of its wind revolution.

\section{Assessment time}

\section{Italy's proposed university reform must be linked to performance.}

A s Rome burned last week during anti-government riots, many of those present were focusing on the plight of Italy's underfunded and underperforming universities, which face major reform. There is no doubt that reform is needed. The question is whether the government will deliver it correctly.

Islands of excellence exist in Italian universities, particularly in the north of the country. And they survive despite such low levels of government investment that little cash remains for infrastructure or research once salaries have been paid. But malaise is widespread, and money is not the only question. University workforces are riddled with dead wood, a legacy of too little competition for academic posts or research grants. And universities are not penalized if they choose to hire staff on the basis of personal contacts instead of talent.

A controversial new law, expected to be approved this week, attempts to fix these issues. It is imperfect, but if implemented properly, it will give Italy's universities a brighter future. Critical to its implementation, 
though, is the prompt creation of a long-promised evaluation agency to assess teaching and research performance and link them to university budgets. Also critical is money - just as throwing money at the problem won't solve the malaise on its own, reforms without additional funds won't be effective.

A law to reform universities was drafted in 2007 by the previous, centre-left government, which also proposed setting up an evaluation agency, known as ANVUR (National Agency for the Evaluation of the University and Research System), modelled on France's AERES agency. The current, centre-right government picked up and tweaked that draft. In doing so, it inserted the authority of its powerful finance ministry, which will directly manage some funds, and sign off annual budgets and budget proposals for each university. But the law also introduces some radical changes that could improve things. For example, it brings in mandatory peer review of all public research money, requiring that $30 \%$ of individuals who sit on peer-review committees are working abroad. This will help to avert high-profile debacles like the ministry of health's behind-closed-doors allocation in 2007 of a $€ 3$-million (US\$4-million) grant from its stem-cell research fund to scientists at a private foundation who claimed to be working more ethically than others - and the reversal of that decision following public outcry.

Changes in the system for recruiting staff may also help, but not necessarily. Traditionally, academic staff have been selected by national committees and then allocated to universities to fill relevant vacancies. Incomprehensible to many of those in other countries, where universities choose their own staff, the 'concorsi' system was intended to challenge a tendency to recruit locally, without necessarily

choosing the best. But behind-the-scenes dealing among concorsi committees ensured that universities mostly got the candidates they wanted anyway, for good or bad. Extensive tinkering in the past decade or so has not yet found a better balance between quality control at a national level and local university autonomy. In the new system, all candidates who pass a national qualification exam, judged by commit-

"Italians are familiar with fine-sounding reforms that fail to actually change things." tees similar to concorsi committees, will join a national list from which a university may at any time select a candidate. The danger here is that less academically suitable people may get on the list, because - as there is no link to a concrete academic position - committees don't bear responsibility for their choices.

Italians are familiar with fine-sounding reforms, such as the attempts to improve the concorsi system, that fail to actually change things. They enjoy quoting Giuseppe Tomasi di Lampedusa's The Leopard, a novel set around the time of Italy's unification in 1861, in which a protagonist observes contemporary politics, and wryly notes how the newly empowered try to 'change everything, so that everything remains the same'. But this law has a strong chance of changing things so that they do become different - and better. A crucial foundation for such success is that the government makes ANVUR happen soon. It was, after all, founded in law in February this year. Now, Italian scientists must see it built in bricks and mortar. The system needs more money, but that money must be linked to performance. Establishing ANVUR would show that Italy has placed its university system on the road to true reform.

\section{Calm in a crisis}

\section{Jane Lubchenco, Nature's Newsmaker of the Year, shows how scientists can help society.}

$\mathrm{F}$ or almost three months this year, a mini-volcano of oil and gas erupted into the Gulf of Mexico and disgorged nearly 5 million barrels of petroleum. Throughout the crisis, a poised scientist gave countless media interviews to explain to a scared and angry public how the US government was striving to contain the damage. Behind the scenes, with decisive leadership, she ran the National Oceanic and Atmospheric Administration (NOAA) - the agency that closed fisheries, tracked oil, protected habitats and assessed the damage to communities and the environment. For her role in the response to the crisis, Jane Lubchenco is Nature's Newsmaker of the Year (see page 1024).

Before becoming NOAA administrator in 2009, Lubchenco had a reputation as both a leading researcher and an environmental advocate. She made important advances in the basic science of coastal ecology and helped to raise awareness of the many threats to ocean ecosystems around the world. Lubchenco is now reorienting her US\$4.7-billion federal agency to strengthen the science and policies that protect US marine resources.

The United States could do with more scientists like Lubchenco, with the skills and the dedication to speak out on issues that matter. The need will be particularly acute next year, when the Republican Party takes over the US House of Representatives. Although Republicans have generally supported basic science, incoming House leaders have made it clear that they are hostile to certain areas of research. Some have pledged to hold hearings on climate science, which they argue is seriously flawed and has overstated the evidence for global warming. Adrian Smith (Republican, Nebraska) introduced the YouCut Citizen Review, which calls on the US public to search the National Science Foundation website list of peer-reviewed grants for those they consider wasteful. And Darrell Issa (Republican, California), the incoming head of the powerful Committee

on Oversight and Government Reform, last year led an effort to revoke funding from the National Institutes of Health for studies of substance abuse and HIV risk in other countries (see Nature 460, 667; 2009).

Scientific leaders in the United States must stand up against such attacks. As a first step, they should try to meet with incoming House members from both parties to voice their concerns and explain the rationale behind research in controversial areas. Recognizing that all politics is local, scientists will need to make clear why climate change or HIV research matters for the communities represented by members of Congress. They should take along science-savvy business leaders and locally elected officials to help make their case.

Beyond the scientific leadership, there is a broader need for more individual scientists to communicate with the public. Currently, that kind of activity is not particularly valued - and is even disdained - in some fields of research. And spending time meeting with elected leaders or local journalists does not help a young scientist to get tenure.

Most scientists receive no training in public communication, and will need to hone their skills. Some can learn from experienced mentors; others can benefit from programmes developed by scientific societies and other groups (see page 1032). Members of academic and government agencies can consult with public-affairs representatives, who can show them the best ways to communicate the results and implications of research. Another avenue is the Congressional Science Fellowship programme, through which scientific societies can sponsor scientists to work in congressional offices for a year, providing advice to elected officials. The societies involved should expand their programmes, and groups that do not currently sponsor fellows should consider it.

As with any endeavour, it takes time to develop the communication skills that Lubchenco and other senior scientists have acquired. Even Lubchenco foundered at times during the oil spill. She made some mistakes and was criticized for the way that her agency initially downplayed the evidence for oil spreading below the surface. Despite such

$\checkmark$ NATURE.COM To comment online, click on Editorials at: go.nature.com/xhunqv slips, Lubchenco has steered her agency through the crisis with a steady hand. She is an outstanding example of how much one scientist can do to improve both society and natural ecosystems. Others would do well to follow her lead. 